NOTICE: This is the author's version of a work that was accepted for publication in Fuel. Changes resulting from the publishing process, such as peer review, editing, corrections, structural formatting, and other quality control mechanisms may not be reflected in this document. Changes may have been made to this work since it was submitted for publication. A definitive version was subsequently published in Fuel, Vol. 120 (2014). doi: 10.1016/j.fuel.2013.12.003 


\title{
A review of the alumina recovery from coal fly ash, with a focus in
}

\section{China}

\author{
Z.T. Yao ${ }^{\mathrm{a}, *, 1}$, M.S. Xia ${ }^{\mathrm{b}, \mathrm{c}^{*}, 1}$, P.K. Sarker ${ }^{\mathrm{d}}$ and T. Chen ${ }^{\mathrm{b}}$ \\ ${ }^{a}$ College of Materials Science and Environmental Engineering, Hangzhou Dianzi University, \\ Hangzhou 310018, China \\ ${ }^{b}$ Department of Ocean Science and Engineering, Zhejiang University, Hangzhou 310058, China \\ ${ }^{\mathrm{c}}$ State Key Laboratory of Satellite Ocean Environment Dynamics, Second Institute of Oceanography, \\ State Oceanic Administration, Hangzhou 310012, China \\ ${ }^{\mathrm{d}}$ Department of Civil Engineering, Curtin University of Technology, Perth, WA 6845, Australia
}

\footnotetext{
*Corresponding authors. Tel./fax: (86) 57186919158.

E-mail address: sxyzt@126.com; ztyao@hdu.edu.cn (Z.T. YAO)

${ }^{1}$ The authors contributed to the work equally and should be regarded as co-first authors
}

\begin{abstract}
Coal fly ash, an industrial by-product, is derived from coal combustion in thermal power plants. It is one of the most complex and abundant of anthropogenic materials, and its improper disposal has become an environmental concern and resulted in a waste of recoverable resources. Coal fly ash is rich in alumina, making it a potential substitute for bauxite. With the diminishing reserves of bauxite resources as well as the increasing demand for alumina, recovering alumina from fly ash has attracted extensive attentions. The present review first describes the alumina recovery history and technologies, and then focuses on the recovery status in China. Finally, the current status of fly ash recycling and directions for future research are considered.
\end{abstract}

Keywords: coal fly ash; recycling; alumina; bauxite; recovery technologies 


\section{Introduction}

Coal fly ash, a by-product of coal combustion in thermal power plants, is one of the most complex and abundant of anthropogenic materials. It accounts for 5 20 wt.\% of feed coal and is typically found in the form of coarse bottom ash and fine fly ash, which represent $70 \sim 85$ and 15 30 wt.\% of the total ash generated, respectively. The generation of coal fly ash is anticipated to increase for many more years, as a result of the world's increasing reliance on coal-fired power generation. A more up-to-date estimate of annual worldwide generation of fly ash is 750 million tonnes [1]. In India, approximately 140 million tonnes is presently generated annually. Total generation in the U.S. and the E.U. is estimated to be around 115 million tonnes per annum. Figure 1 shows the generation of coal fly ash in China, from 2001 to 2015. Annual generation is still increasing and is anticipated to reach 580 million tonnes by 2015.

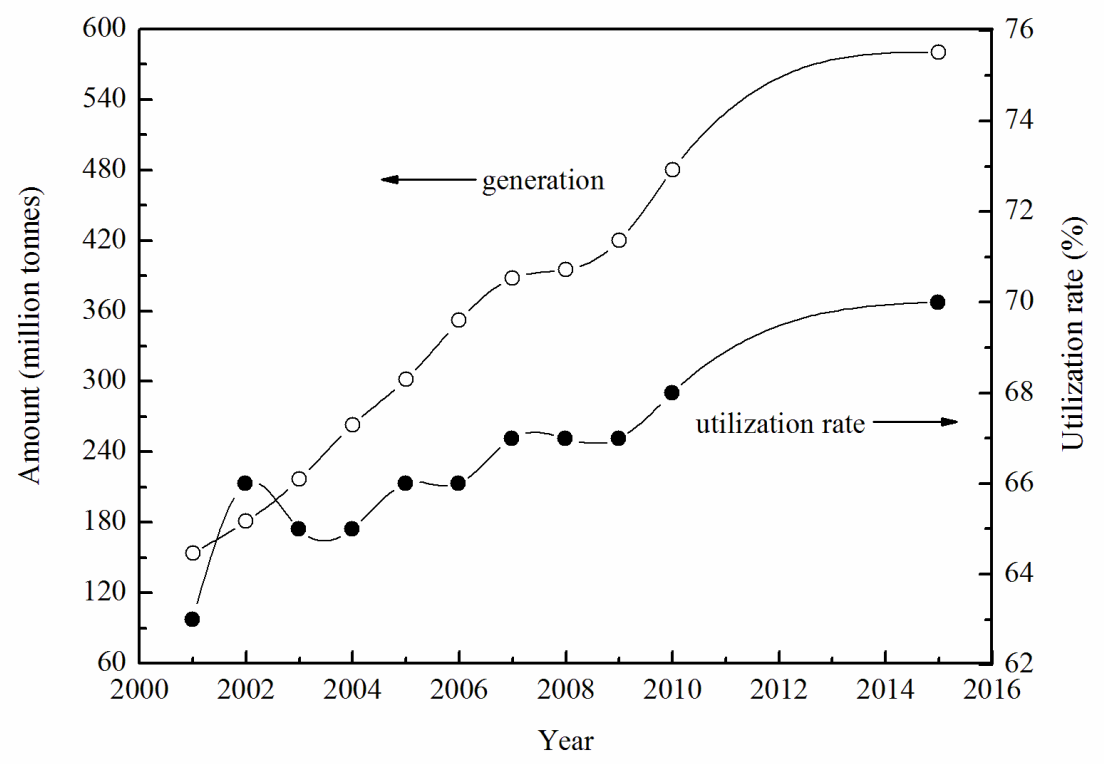

Fig. 1 The generation and utilization of coal fly ash in China 
The environmental impact of coal fly ash is now being fully recognized. Most ash disposal methods ultimately lead to the dumping of fly ash on open land. Irregular accumulation and inappropriate disposal of fly ash will lead to its disposal over vast areas of land, with resultant degradation of the soil and danger to both human health and the environment. Fly ash particles are small enough to escape emission control devices, are easily suspended in air and have become a major source of gas pollution. Repeated exposure to fly ash can cause irritation of the eyes, skin, nose, throat and respiratory tract, and can even result in arsenic poisoning. Fly ash can even reach the sub-soil and ultimately cause siltation, clog natural drainage systems and contaminate the ground water with heavy metals. During coal combustion, most of $U$, Th and their decay products are released from the original coal matrix and are distributed between the gas phase and the solid combustion products.

Recycling coal fly ash can be a good alternative to disposal, and could achieve significant economic and environmental benefits as well. More aggressive efforts have been undertaken recently, to recycle fly ash [2,3]. For example, about $20 \%$ of the fly ash generated is being used in concrete production. Other uses include soil amelioration [4-6], ceramic industry [7-9], catalysis and support for catalysis [10-13], adsorbents for removal of various pollutants [14], depth separation [15-17], zeolite synthesis [18-20] and valuable metals recovery [21-23]. The global average utilization rate of fly ash is estimated to be nearly $25 \%$ [24]. Current utilization rates have been estimated at $39 \%$ for U.S., $47 \%$ for the E.U. and $15 \%$ for India [25, 26]. For China, this rate has been increasing annually but has remained around $67 \%$ in recent years. It is expected to reach $70 \%$ by 2015 (see Fig. 1). However, there is a contradiction in the reported utilization 
rate in China; Greenpeace reported that the practical utilization rate is only 30\% [27]. Whatever the exact figure, it is clear that a significant proportion of coal fly ash will be left untreated and that there is an urgent need for developing new recycling methods for it.

Understanding the chemical and mineralogical properties of coal fly ash is important, as these properties influence its use and disposal. Coal fly ash is one of the most complex of the materials that can be characterized [28]. The major crystalline phases characterized are mullite and quartz for most ash and major components are metallic oxides with varying contents of unburnt carbon. The contents of principal oxides are, in descending order: $\mathrm{SiO}_{2}>\mathrm{Al}_{2} \mathrm{O}_{3}>\mathrm{Fe}_{2} \mathrm{O}_{3}>\mathrm{CaO}>\mathrm{MgO}>\mathrm{K}_{2} \mathrm{O}$. Coal fly ash is rich in alumium, making it a potential source of alumina. With the diminishing of bauxite resources as well as the increase in alumina demand, the profitable industrial utilization of coal fly ash in alumina recovery has attracted extensive attentions.

\section{Alumina recovery}

\subsection{History}

The recovery of alumina from coal fly ash was pioneered by Grzymek in Poland in the 1950s [29], and was developed mainly because of the bauxite embargo during the Cold War. The recovery process was based on the auto-disintegration of sinter containing calcium aluminates and dicalcium silicate [30]. The sinter was mixed with sodium carbonate and underwent a series of complicated chemical treatments including carbonization and water scrubbing to produce alumina and Portland cement. In 1953, a demonstration plant for recovering 10 thousand tonnes of alumina and producing 100 thousand tonnes of Portland cement was established in Poland. At the end of the 1970s, a 
second plant was established with the capability of producing 100 thousand tonnes of alumina and 1.2 million tonnes of cement. In the early 1970's, there was widespread concern about an impending producers' cartel of bauxite exporters, leading to higher prices. This concern led the U.S. Bureau of Mines to undertake a major program of research into potential alternatives to bauxite. The processes studied included variations of existing leaching and sintering processes. Since the 1980s, more researches have been conducted and new recovery technologies developed as well.

\subsection{Recovery technologies}

All commercial production of alumina from bauxite is performed by a process patented by Bayer in 1888 [31]. As bauxite is sufficiently rich in aluminum hydroxide minerals and low in impurities, and the alumina can be extracted relatively easily and inexpensively, any alternate methods for extracting alumina must be economically competitive with the Bayer process. Unlike bauxite, fly ash shows the characteristics of relatively low content of alumina, high content of silica, and the presence of aluminum mainly in the form of chemically stable mullite, which may lead to a low alumina recovery rate and high capital and operating costs. Recently, a number of processes for recovering alumina from coal fly ash have been reported, which can be grouped into three types: the sinter process, the acid leach process and the HiChlor process (see Table 1). 
Table 1 The comparision of different alumina recovery technologies

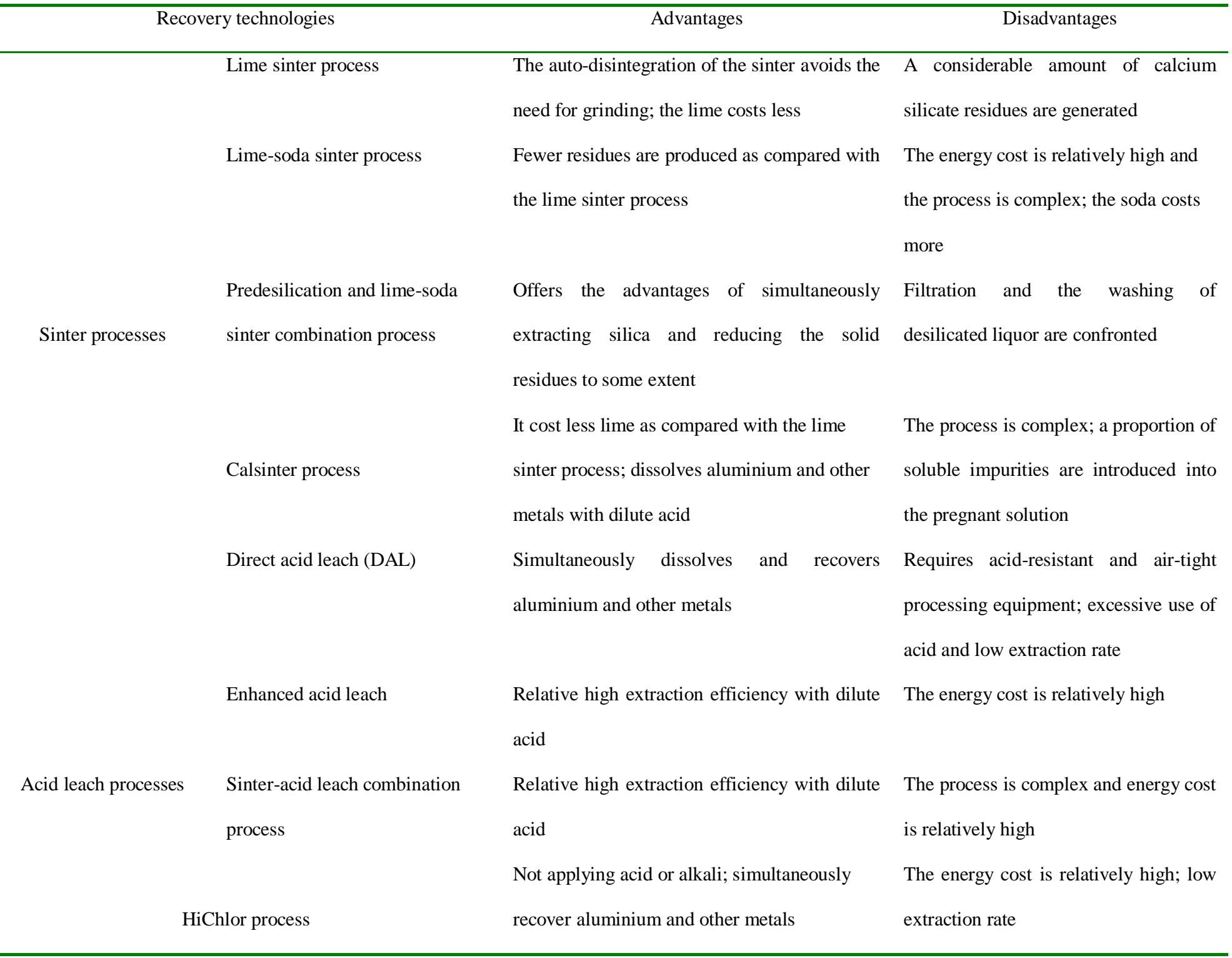

\section{Sinter processes}

According to the sintering mediums, the sinter processes can be classified into: lime or lime-soda sinter, the Calsinter process and other sinter processes (e.g. salt-soda sinter, ammonium sulfate sinter and fluorides sinter). The sinter processes involve a high-temperature reaction of coal fly ash with powdered sintering agents to form soluble 
alumina compounds. The sinter is then leached to separate aluminium, and the pregnant solution is subsequently treated to prepare alumina with high purity.

\section{(1) Lime sinter process}

The lime sinter process is a modification of the Pederson process which was used to produce pig iron and calcium aluminate slags from a mixture of bauxite, iron ore, coke and limestone $[32,33]$. Alumina was recovered in the Pederson process by leaching the slag with a sodium carbonate solution. In the lime sinter process, the fly ash reacts with lime (added as limestone) at elevated temperature $\left(>1100^{\circ} \mathrm{C}\right)$ forming calcium aluminate, soluble in the extractant, and dicalcium silicate, insoluble in the same solution. The extraction of alumina from the sinter is carried out by dissolving the soluble alumina into the extractant and leaving the calcium silicate in the solid residues. The common extractants include water and dilute alkaline solutions, such as $\mathrm{Na}_{2} \mathrm{CO}_{3}$ and $\mathrm{NaOH}$ solutions [34]. After leaching, the aluminium in the pregnant liquor is subsequently precipitated as $\mathrm{Al}(\mathrm{OH})_{3}$ by contacting the solution with $\mathrm{CO}_{2}$. The next step is calcination of the precipitate to produce the final product $\alpha$ - or $\gamma$-alumina. The solid residues from the leaching step are sintered and mixed with gypsum during grinding to prepare cement. The schematic diagram of the lime sinter process is illustrated in Fig. 2. The major steps involved are described as follows:

Sintering of raw materials: The sintering step is conducted to activate the coal fly ash. The limestone is first dissociated into calcium oxide at high temperature. The inactive mullite and quartz in the ash then react with $\mathrm{CaO}$, forming $12 \mathrm{CaO} \cdot 7 \mathrm{Al}_{2} \mathrm{O}_{3}$ and $2 \mathrm{CaO} \cdot \mathrm{SiO}_{2}$, respectively. Forming $12 \mathrm{CaO} \cdot 7 \mathrm{Al}_{2} \mathrm{O}_{3}$ is the perquisite of the lime sinter process. This sinter product is easily dissolved in the extractant, forming $\mathrm{NaAlO}_{2}$. 
However, Hignett [35] reported $5 \mathrm{CaO} \cdot 3 \mathrm{Al}_{2} \mathrm{O}_{3}$ as the most soluble aluminate, and the formation of other calcium aluminates is unavoidable in this process. $3 \mathrm{CaO} \cdot \mathrm{Al}_{2} \mathrm{O}_{3}$ and $\mathrm{CaO} \cdot \mathrm{Al}_{2} \mathrm{O}_{3}$ can form depending on the availability of $\mathrm{CaO}$ in the mixture. These two compounds are not as soluble as $12 \mathrm{CaO} \cdot 7 \mathrm{Al}_{2} \mathrm{O}_{3}$. The formed $2 \mathrm{CaO} \cdot \mathrm{SiO}_{2}$ is hardly dissolved at all, which is helpful for the separation of aluminium and silicon. The chemical reaction equations involved in this process can be presented as follows:

$$
\begin{gathered}
\mathrm{CaCO}_{3} \rightarrow \mathrm{CaO}+\mathrm{CO}_{2} \\
7\left(3 \mathrm{Al}_{2} \mathrm{O}_{3} \cdot 2 \mathrm{SiO}_{2}\right)+64 \mathrm{CaO} \rightarrow 3\left(12 \mathrm{CaO} \cdot 7 \mathrm{Al}_{2} \mathrm{O}_{3}\right)+14\left(2 \mathrm{CaO} \cdot \mathrm{SiO}_{2}\right) \\
3 \mathrm{Al}_{2} \mathrm{O}_{3} \cdot 2 \mathrm{SiO}_{2}+13 \mathrm{CaO} \rightarrow 3\left(3 \mathrm{CaO} \cdot \mathrm{Al}_{2} \mathrm{O}_{3}\right)+2\left(2 \mathrm{CaO} \cdot \mathrm{SiO}_{2}\right) \\
3 \mathrm{Al}_{2} \mathrm{O}_{3} \cdot 2 \mathrm{SiO}_{2}+5 \mathrm{CaO} \rightarrow 3\left(\mathrm{CaO} \cdot \mathrm{Al}_{2} \mathrm{O}_{3}\right)+2\left(\mathrm{CaO} \cdot \mathrm{SiO}_{2}\right) \\
2 \mathrm{CaO}+\mathrm{SiO}_{2} \rightarrow 2 \mathrm{CaO} \cdot \mathrm{SiO}_{2}
\end{gathered}
$$

Auto-disintegration of the sinters: During cooling (temperature below $500{ }^{\circ} \mathrm{C}$ ), auto-disintegration of the sinter occurs, a phenomenon attributed to the transformation from the metastable, monoclinic $\beta$ polymorph of $2 \mathrm{CaO} \cdot \mathrm{SiO}_{2}$ to the orthorhombic $\gamma$ polymorph. The transformation is accompanied by an $11 \%$ volume increase, resulting in the matrix shattering into fine powder. This disintegration is helpful and avoids the need for grinding the sinters $[36,37]$.

Leaching of the sinters: The cooled sinter is leached by an $\mathrm{Na}_{2} \mathrm{CO}_{3}$ solution. After leaching, the aluminium remains in the leachate in the form of $\mathrm{NaAlO}_{2}$, while most silicon is left as solid residue in the form of $2 \mathrm{CaO} \cdot \mathrm{SiO}_{2}$, achieving the separation of aluminium and silicon. For the high levels of $3 \mathrm{CaO} \cdot \mathrm{Al}_{2} \mathrm{O}_{3}$ and $\mathrm{CaO} \cdot \mathrm{Al}_{2} \mathrm{O}_{3}$ formed in 
the sintering step, the extractant must contain an excess of $\mathrm{Na}_{2} \mathrm{CO}_{3}$ for maximum alumina extraction. The following equations represent these transformations:

$$
\begin{gathered}
12 \mathrm{CaO} \cdot 7 \mathrm{Al}_{2} \mathrm{O}_{3}+12 \mathrm{Na}_{2} \mathrm{CO}_{3}+5 \mathrm{H}_{2} \mathrm{O} \rightarrow 14 \mathrm{NaAlO}_{2}+12 \mathrm{CaCO}_{3}+10 \mathrm{NaOH} \\
3 \mathrm{CaO} \cdot \mathrm{Al}_{2} \mathrm{O}_{3}+3 \mathrm{Na}_{2} \mathrm{CO}_{3}+2 \mathrm{H}_{2} \mathrm{O} \rightarrow 2 \mathrm{NaAlO}_{2}+3 \mathrm{CaCO}_{3}+4 \mathrm{NaOH} \\
\mathrm{CaO} \cdot \mathrm{Al}_{2} \mathrm{O}_{3}+\mathrm{Na}_{2} \mathrm{CO}_{3} \rightarrow 2 \mathrm{NaAlO}_{2}+\mathrm{CaCO}_{3} \\
2 \mathrm{CaO} \cdot \mathrm{SiO}_{2}+2 \mathrm{Na}_{2} \mathrm{CO}_{3} \rightarrow 2 \mathrm{CaCO}_{3}+2 \mathrm{NaOH}+\mathrm{NaSiO}_{3} \\
2 \mathrm{CaO} \cdot \mathrm{SiO}_{2}+2 \mathrm{NaOH}+\mathrm{H}_{2} \mathrm{O} \rightarrow 2 \mathrm{Ca}(\mathrm{OH})_{2}+\mathrm{Na}_{2} \mathrm{SiO}_{3}
\end{gathered}
$$

Desilication of the crude leachate: Ideally all silica is fixed as insoluble residues in this process. However, the dissolution of small amounts of silicon during leaching is unavoidable, as is validated by the equations (9) and (10). It has been reported that a $2 \sim 3 \%$ (alumina basis) is the typical concentration of silica in the lime sinter process [38]. Hignett [35] reported the soluble alumina produced in the pilot plant as lower than that in the laboratory test. One of the major problems was the control of the silica content of the solution in the pilot plant. The silica concentration in the leachate could be decreased to less than $0.02 \%$ (alumina basis) by agitating the solution in the presence of lime at $70{ }^{\circ} \mathrm{C}$. Therefore, the lime sinter process usually includes a step for Al-rich solution purification before the precipitation of aluminium. The desilication is conducted mostly by adding $\mathrm{Ca}(\mathrm{OH})_{2}$ suspensions to make the silicon transform into calcium aluminosilicates with relatively low solubility. The reaction is described as follows:

$$
\begin{gathered}
2 \mathrm{Na}_{2} \mathrm{SiO}_{3}+2 \mathrm{NaAlO}_{2}+\mathrm{Ca}(\mathrm{OH})_{2}+2 \mathrm{H}_{2} \mathrm{O} \rightarrow \mathrm{CaO} \cdot \mathrm{Al}_{2} \mathrm{O}_{3} \cdot 2 \mathrm{SiO}_{2}+6 \mathrm{NaOH} \\
\mathrm{Na}_{2} \mathrm{CO}_{3}+\mathrm{Ca}(\mathrm{OH})_{2} \rightarrow \mathrm{CaCO}+2 \mathrm{NaOH}
\end{gathered}
$$

Carbonization of the refined solution: $\mathrm{CO}_{2}$ gas is blown into the desilicated 
$\mathrm{NaAlO}_{2}$ solution from the bottom, followed by vigorous stirring. The $\mathrm{NaAlO}_{2}$ hydrolyzes to form the precipitate $\mathrm{Al}(\mathrm{OH})_{3}$ when the $\mathrm{pH}$ falls to a certain value. The initially formed $\mathrm{Al}(\mathrm{OH})_{3}$ particles are easy to aggregate due to the high surface activity, which could induce the small particles to grow into larger ones. The addition of dispersing agents with high performance (e.g. polyethylene glycol, polyving akohol) can control the shape of the precipitate and make filtration easy. Lin et al. [39] added 0.1\% dispersing agent prepared from ammonium acrylate and acrylamide into the enriched $\mathrm{NaAlO}_{2}$ solution, and ultrafine $\mathrm{Al}(\mathrm{OH})_{3}$ powder was obtained. The following equations represent these transformations:

$$
\begin{aligned}
2 \mathrm{NaAlO}_{2}+\mathrm{CO}_{2}+3 \mathrm{H}_{2} \mathrm{O} & \rightarrow \mathrm{Na}_{2} \mathrm{CO}_{3}+2 \mathrm{Al}(\mathrm{OH})_{3} \\
2 \mathrm{NaOH}+\mathrm{CO}_{2} & \rightarrow \mathrm{Na}_{2} \mathrm{CO}_{3}+\mathrm{H}_{2} \mathrm{O}
\end{aligned}
$$

Calcination of the precipitate: The obtained $\mathrm{Al}(\mathrm{OH})_{3}$ is calcined based on the Thermo-Gravimetric/Differential Thermal Analyzer (TG-DTA) and X-ray diffraction (XRD) analysis to transform into $\mathrm{Al}_{2} \mathrm{O}_{3}$ with high purity. The chemical reaction that occurs is:

$$
2 \mathrm{Al}(\mathrm{OH})_{3} \rightarrow \mathrm{Al}_{2} \mathrm{O}_{3}+3 \mathrm{H}_{2} \mathrm{O}
$$




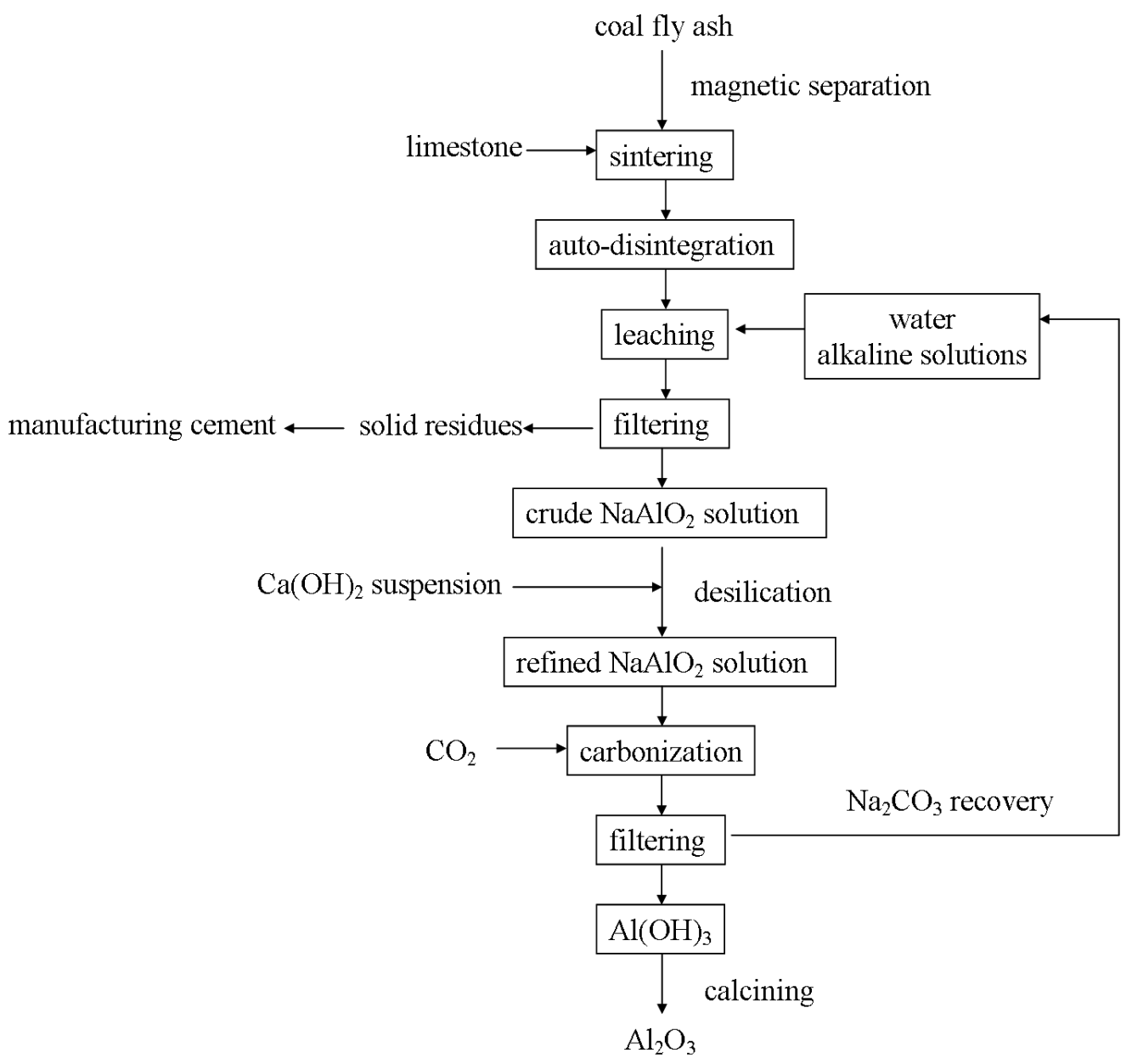

Fig. 2 Schematic diagram of lime sinter process

\section{(2) Lime-soda sinter process}

The first lime-soda sinter process was developed by Kayser in 1902 to separate alumina from silica [40]. The reaction of the mixture of lime and soda with fly ash is known to produce soluble sodium aluminate and insoluble calcium silicate. At high temperatures (generally $1100 \sim 1400{ }^{\circ} \mathrm{C}$ ), the formation of other compounds is unavoidable, depending upon the fly ash type and sintering conditions. As in the lime sinter process, the sintered product is leached with water, caustic soda or sodium carbonate solution. The dissolution of small amounts of silica during leaching is unavoidable. Therefore, the lime-soda sinter process also includes a step for purification 
of the pregnant solution. The resulting slurry is filtered, and the liquor is treated with $\mathrm{Ca}(\mathrm{OH})_{2}$ suspensions to precipitate any dissolved silica at high temperature and pressure, which is then decomposed as in the Bayer process or is treated with $\mathrm{CO}_{2}$ to precipitate hydrated alumina. The $\mathrm{Al}(\mathrm{OH})_{3}$ is separated and can be converted to alumina by calcining. When operated in conjuction with the Bayer process, it is called the combination process. Padilla and Sohn [41] studied the main variables in the sintering step and the kinetics of sodium aluminate formation during sintering. The major sinters were identified as sodium aluminate and $\beta$-dicalcium silicate. Alumina recovery of about $80 \%$ was obtained at optimal conditions. The schematic diagram of the lime-soda sinter process is illustrated in Fig. 3. 


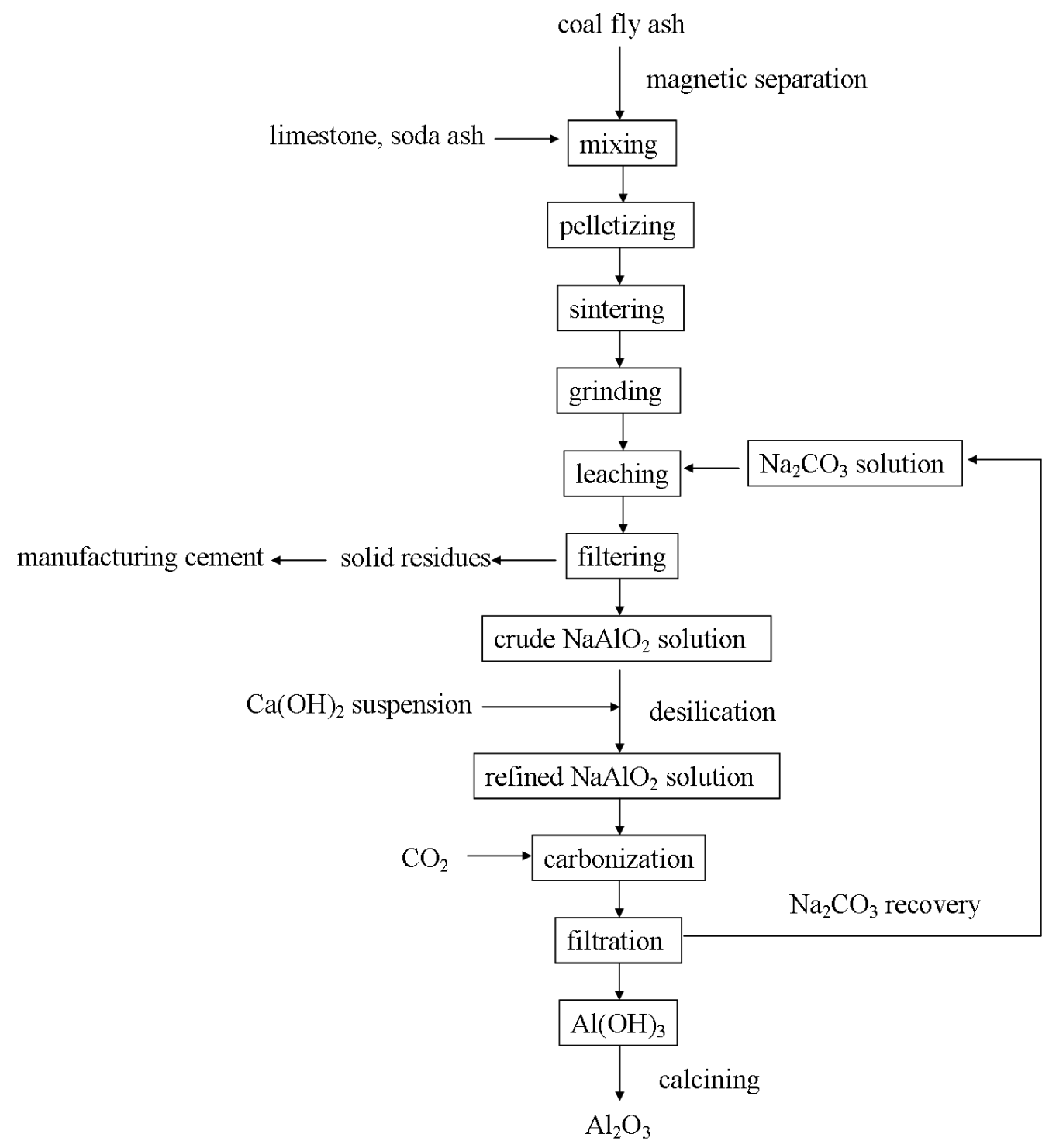

Fig. 3 Schematic diagram of lime-soda sinter process [40]

\section{(3) Predesilication and lime-soda sinter combination process}

The lime and lime-soda sinter processes were developed long ago; however, they are still in the early stages of commercialization. Problems are encountered when the process is used in industry because of the massive lime usage as well as the high energy cost. Besides, a considerable amount of calcium silicate residues are generated, but not utilized in an effective way except by producing cement. It has been roughly calculated that 7 10 
tonnes of calcium silicate residues will be generated in recovering 1 tonne of alumina product. The problem results from the substantial silica content, which contributes to a large consumption of lime. Therefore, it is strictly required that the $\mathrm{Al}_{2} \mathrm{O}_{3} / \mathrm{SiO}_{2}$ mass ratio of the fly ash be about 2 for the lime-soda sintering process. However, when the ratio of fly ash is in the range of $0.8 \sim 1.0$, enriching aluminum content by removing silicon seems to be a good choice.

Except for mullite and crystalline quartz, amorphous and reactive silica is also present in the fly ash, the proportion of which accounts for 30 60 wt.\%. Thus, predesilication followed by a sintering process was developed to reduce the silica content and the consumption of sintering mediums. In addition, the desilicated silicon could be reused as silica white and calcium silicate. Wang et al. [43] extracted aluminia by predesilication of fly ash, lime-soda sinter, waster dissolution and carbonation processes. The desilication rate reached $40 \%$ and the $\mathrm{Al}_{2} \mathrm{O}_{3} / \mathrm{SiO}_{2}$ molar ratio of fly ash increased after predesilication. The extraction rate of alumina from the sinter reached as high as 91\%. Bai et al. [44] recovered alumina from desilicated fly ash by lime-soda sinter process. The recovery rate reached $90 \%$ at the optimal conditions. Bai et al. [45] enriched aluminum in fly ash by alkali desilication and carbonation to transform amorphous silicon dioxide into an amorphous nano-particles product.

\section{(4) Calsinter process}

The Calsinter process was developed at the U.S. Oak Ridge National Laboratory. In this process, coal fly ash is blended and sintered with gypsum and limestone at a temperature of about $1000 \sim 1200{ }^{\circ} \mathrm{C}$. The sinter is then leached with dilute acid. Waste solids are removed by filtration, and metal values are recovered from the filtrate. The 
schematic diagram of this process is displayed in Fig. 4. In 1976, Goodboy [46] reported on the study of alumina extraction from coal waste and clays mixed with limestone and calcium sulfate. Alumina extraction of $90 \%$ was achieved by sintering at $1200{ }^{\circ} \mathrm{C}$ for 15 min. Seeley et al. [47] used the Calsinter process to recover alumina and determine the distribution coefficients for $\mathrm{Fe}^{3+}$ and 16 other metal ions in the liquid-liquid extraction system. The results showed that this process could effectively remove more than $95 \%$ of the aluminum, along with significant amounts of several other metals, from fly ash.

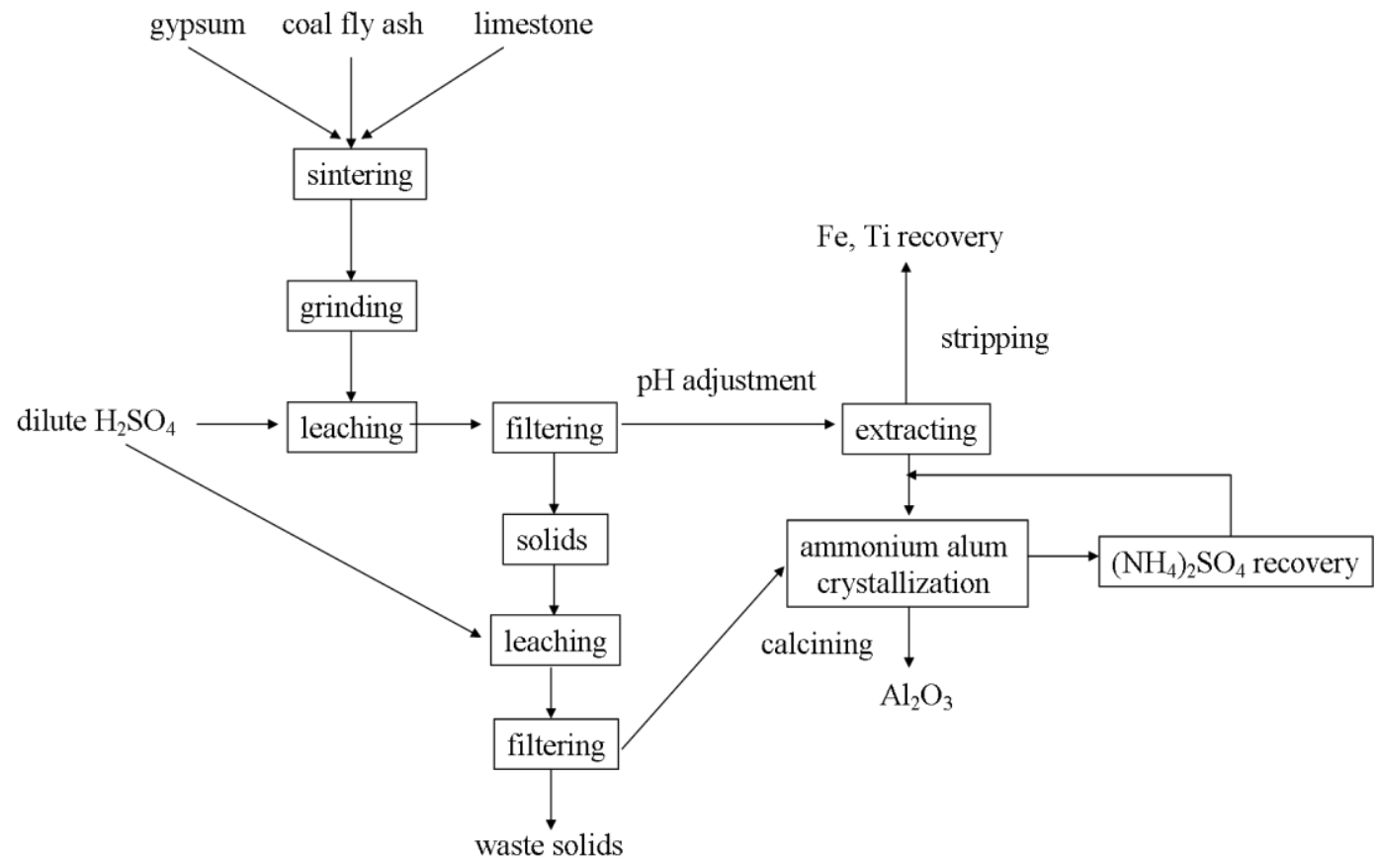

Fig. 4 Schematic diagram of Calsinter process [45]

\section{(5) Other sinter processes}

In addition to the lime and lime-soda sinter, other sinter processes such as salt-soda sinter, ammonium sulfate sinter and fluorides sinter are also reported. In the salt-soda sinter process, a NaCl- $\mathrm{Na}_{2} \mathrm{CO}_{3}$ mixture is sintered with fly ash, quenched in a water leach, and then leached in a dilute acid solution. In U.S. patent US 4254088 A [48], the 
fly ash was first sintered with a mixture of $\mathrm{NaCl}$ and $\mathrm{Na}_{2} \mathrm{CO}_{3}$ at a temperature of 700 900 ${ }^{\circ} \mathrm{C}$. The sinter was then leached with nitric or sulfuric acid, recovering 90 99\% of the aluminum. Decarlo et al. [49] studied the effect of individual components of the salt-soda on the alumina recovery. The fly ash was sintered with $\mathrm{NaCl}$ and successively leached with $\mathrm{Na}_{2} \mathrm{CO}_{3}$ and $\mathrm{HNO}_{3}$ solutions. The alumina recovery was a mere $27 \%$. However, sintering fly ash with $\mathrm{Na}_{2} \mathrm{CO}_{3}$ gave an alumina recovery of $66 \%$. Nehari et al. [50] described a process using $\mathrm{CaCl}_{2}$ as a sintering medium. It consists of sintering fly ash with hydrated $\mathrm{CaCl}_{2}$, leaching the sinter product with $\mathrm{HCl}$ and recovering alumina from the crystallized $\mathrm{AlCl}_{3}$. Decarlo et al. [49] reported that sintering fly ash with $\mathrm{CaCl}_{2}-\mathrm{Na}_{2} \mathrm{CO}_{3}$ and $\mathrm{NaCl}-\mathrm{CaCO}_{3}$, followed by leaching with $\mathrm{H}_{2} \mathrm{O}$ and $\mathrm{HNO}_{3}$ solutions, solubilized 78 and $74 \%$ of the alumina in fly ash, respectively. The leaching rate of fly ash using a $\mathrm{CaCl}_{2}-\mathrm{CaSO}_{4}-\mathrm{NaCl}$ sinter process and $\mathrm{H}_{2} \mathrm{SO}_{4}$ extraction was $30 \%$. Tong et al. [51] sintered fly ash with $\mathrm{KF}$ and leached the sinter product with $\mathrm{HCl}$. The leaching rate reached $96.92 \%$. Alum is commonly synthesized as an intermediate material for the production of alumina from Al-containing nonbauxitic raw materials [52]. Park et al. [53] calcined fly ash with ammonium sulfate at $400{ }^{\circ} \mathrm{C}$ for $2 \mathrm{~h}$ to form $\mathrm{NH}_{4} \mathrm{Al}\left(\mathrm{SO}_{4}\right)_{2}$. High purity alum was precipitated by the reaction of $\mathrm{NH}_{4} \mathrm{Al}\left(\mathrm{SO}_{4}\right)_{2}$ and ammonia in water and then followed by crystallization.

\section{Acid leach processes}

\section{(1) Direct acid leach (DAL)}

Thorough separation of aluminum from silicon can be achieved by the DAL process. It usually uses sulfuric, hydrochloric and nitric acid to leach fly ash. However, the aluminium extraction by DAL at low acid concentration and ambient temperature is not 
suitable for high recovery $[54,55]$. An aqueous suspension of 20\% (w/v) fly ash using 16 $\mathrm{mol} / \mathrm{L} \mathrm{HNO}_{3}$ and $36 \mathrm{~mol} / \mathrm{L} \mathrm{H}_{2} \mathrm{SO}_{4}$ will dissolve no more than $10 \%$ of the total aluminum at ambient temperature over a period of $72 \mathrm{hrs}$. Greater amounts of aluminum are recovered by leaching under reflux conditions for extended periods of time; and even then no more than about half the aluminum is dissolved in the acid leachate [48]. Shemi et al. [56] employed a DAL process to extract aluminium. The sulphuric acid leaching yielded an extraction efficiency of $23.5 \%$. Gudyanga et al. [57] investigated the feasibility of extracting aluminium from fly ash in acid and alkaline media. The results showed that in alkaline solution only aluminium was extracted, to yield 55\% recovery, as compared with $29 \%$ recovery in an acid system. The apparent low recovery of aluminium in low acid concentration may be due to the co-dissolution of silica and the subsequent formation of an unfilterable silica gel [58]. It has been proposed that the glassy phase of fly ash dissolves rapidly and that the more stable quartz-mullite phase which remains dissolves more slowly. The schematic diagram of this process is exhibited in Fig. 5.

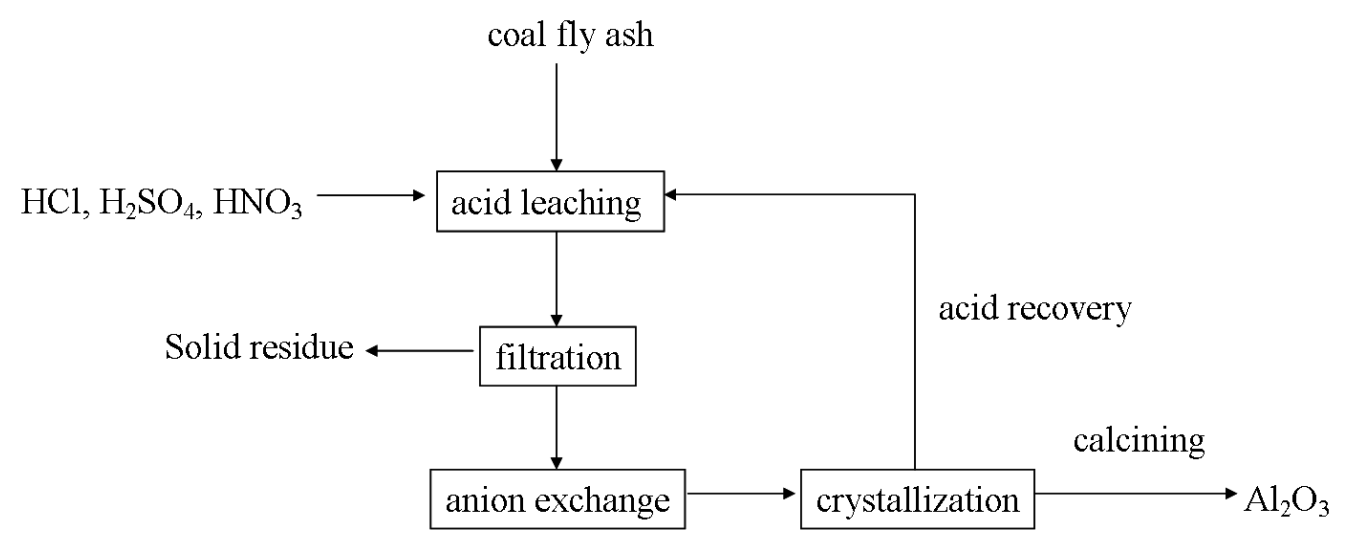

Fig. 5 Schematic diagram of DAL process [57] 


\section{(2) Enhanced acid leach}

Various attempts have been made to improve aluminum extraction efficiency. Wu et al. [60] leached aluminum from fly ash by a pressure acid-leaching method. The optimum conditions were determined to be sulfuric acid concentration of $50 \%$ and reaction temperature of $180{ }^{\circ} \mathrm{C}$ for $4 \mathrm{~h}$. Under optimum conditions, the extraction efficiency reached $82.4 \%$. In comparison to conventional heating processes, microwave heating has inherent advantages in that it can be selective, controllable and efficient. The dissolution of both inorganic and organic materials by an acid can be accelerated due to the effective internal heating caused by microwaves. Gong [61] investigated microwave heat on alumina recovery in the acid leach process and found that the recovery reached above $75 \%$ at optimal conditions.

\section{(3) Sinter-acid leach combination process}

The industrial applications of acid leach processes have been limited due to their excessive use of acid and fluoride. This limitation can be lifted by calcining fly ash with concentrated sulfuric acid at high temperature. Liu et al. [62] and Bai et al. [63] extracted alumina using an acid sinter-leach combination process. The fly ash and concentrated sulfuric acid mixture was calcined to transform most of the aluminum into aluminum sulfate, which can be extracted by hot water. The rate of alumina recovery can reach 70 90 \% with relative lower processing temperatures and less solid residue. Ji et al. [64] calcined fly ash with soda at $900{ }^{\circ} \mathrm{C}$ to yield soluble aluminates. The sinter was then leached with sulfuric acid to produce a solution containing aluminum. The extraction efficiency reached as high as above $98 \%$. Matjie et al. [65] calcined fly ash with $\mathrm{CaO}$ at a temperature range of $1000 \sim 1200{ }^{\circ} \mathrm{C}$. An aluminium extraction efficiency of $85 \%$ was 
achieved when the sinter was leached with sulphuric acid using an acid concentration of $6.12 \mathrm{~mol} / \mathrm{L}$ at $80{ }^{\circ} \mathrm{C}$ for $4 \mathrm{~h}$.

\section{HiChlor process}

An alternative route for extracting aluminum and other metals is to chlorinate ash, a method investigated by Burnet et al. [66]. As a first step, the separation of a magnetic fraction of fly ash was conducted. However, this still left about one third of the iron, with the nonmagnetic fraction and about $10 \%$ of the total aluminum lost to the magnetic fraction. Moreover, in the chlorination step, the nonmagnetic fraction of fly ash was mixed with carbon and chlorinated in a fixed bed. To obtain aluminum metal, the recovered aluminum chloride can be decomposed electrolytically. The technology for this electrolysis step is commercially available. Interestingly, only $70 \%$ as much electrical energy is needed to obtain pure metal from aluminum chloride as from bauxite [67]. Mehrotra et al. [67] investigated the high-temperature chlorination of fly ash using a gas-fluidized bed reactor. With carbon and carbon monoxide present as reducing agents, about $25 \%$ of the alumina in ash could be chlorinated in $2 \mathrm{~h}$ at temperatures above $900{ }^{\circ} \mathrm{C}$.

\section{Alumina recovery status in China}

At present, China is dependent mainly on imports for bauxite, the major source of aluminum. The total alumina demand was 33.86 million tonnes in 2009, while the domestic production of alumina was only 23.79 million tonnes. Imported alumina and bauxite amounts were 5.14 and 19.69 million tonnes, respectively. More than $40 \%$ of the bauxite has been supplied from imports in recent years, $90 \%$ of which are from Indonesia and Australia. 
The feasibility of alumina recovery from fly ash mainly depends on its alumina content. Usually fly ash with alumina content of more than $30 \%$ can be considered feasible for the recovery of alumina. The average alumina content of the fly ash produced in China is found to range from 20 to $35 \%$, as determined by analyzing the fly ash produced by the large scale thermal power stations [68]. However, the ash produced in southern Inner Mongolia, northern Shanxi and the Shaanxi province of China are characterized by its high aluminum content. The alumina content is in the range of 40 45\% and in some cases it could reach as high as approximately 50\%. The high alumina content of fly ash could meet the demand of the Bayer process for alumina production and makes it a potential substitute for bauxite $[69,70]$. The proven coal reserves with high content of aluminium in the Junggar basin, Daqing Shan mountain, and Zhuozi Shan mountain in Inner Mongolia is about 50 billion tonnes. It is expected that 15 billion tonnes of coal fly ash will be generated and 5 billion tonnes of alumina recovered, which is equivalent to 12 billion tonnes of bauxite and 3.2 times the proven bauxite resources in China.

To encourage and support the comprehensive utilization of coal fly ash, the National Development and Reform Commission (NDRC) of China issued a newly revised joint decree "Utilization of fly ash management approach" in February 2011. In March, the NDRC and relevant departments of the State Council amended the "Guidance Catalogue for Industrial Structure Adjustment (2005 edition)". Fly ash with a high content of aluminum was listed in the encouraged items in the "2011 edition." Under a series of encouraged and preferential policies issued by the state and local goverment, the recovery of alumina from fly ash is being aggressively undertaken. Consistent with the distribution 


\section{of high-alumina fly ash, the plants established are mainly in Inner Mongolia and Shanxi}

\section{province (see Fig. 6). Detailed information on the projects is listed in Table 2.}

\section{Table 2 Plants performing alumina recovery from coal fly ash in China}

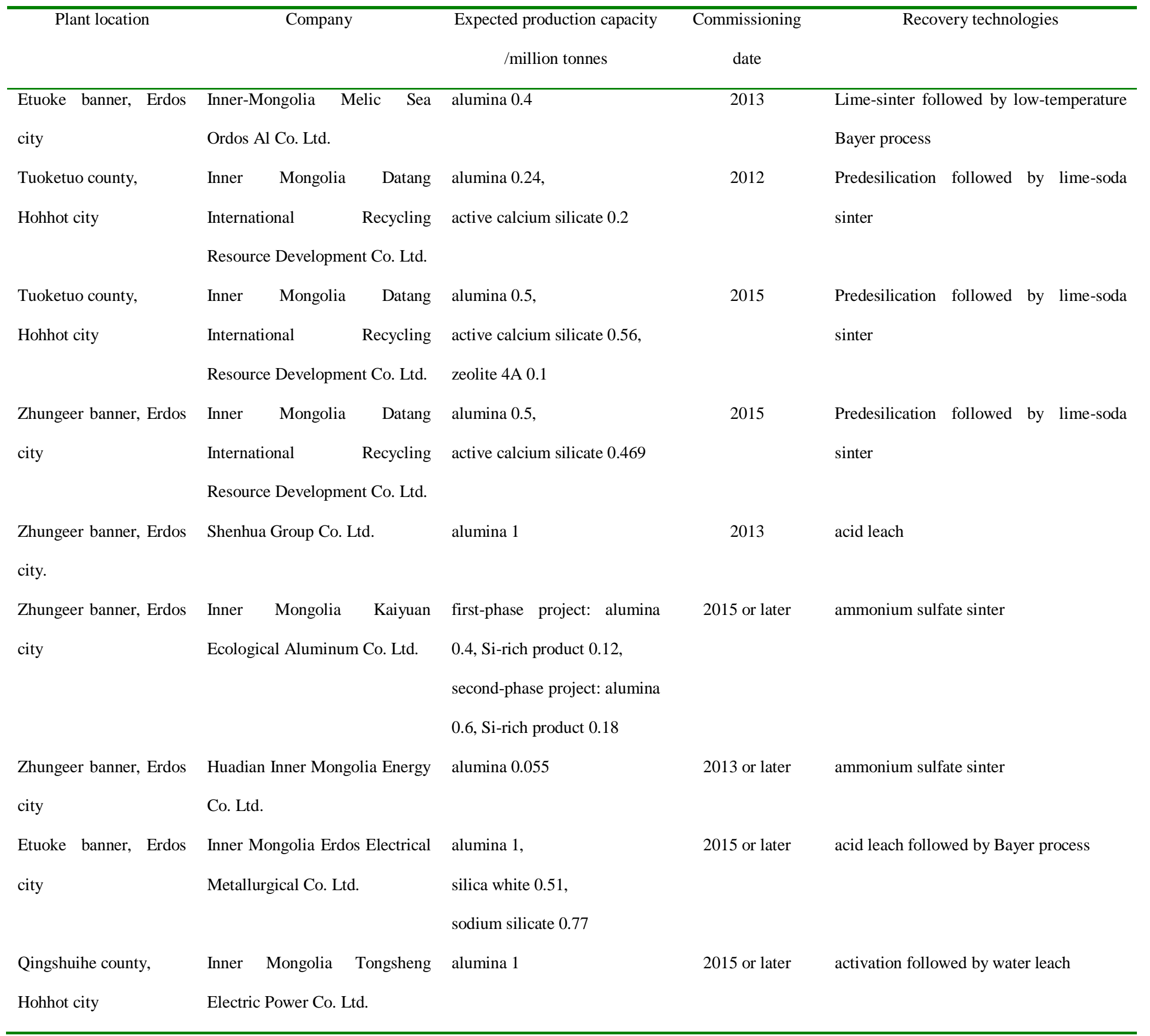




\begin{tabular}{|c|c|c|c|c|}
\hline Zhungeer banner, Erdos & qianhengxing & first-phase project: alumina & 2013 or later & - \\
\hline city & Industrial Co. Ltd. & 1.2 & & \\
\hline Shuozhou city, Shanxi & China Coal Pingshuo Coal & alumina 0.1 & 2013 & predesilication followed by lime-soda \\
\hline province & Industry Co. Ltd. & silica white 0.04 & & sinter \\
\hline Baicheng city, Jilin & - & alumina 0.2 & - & alkali sinter-acid leach \\
\hline province & & silica white 0.2 & & \\
\hline
\end{tabular}

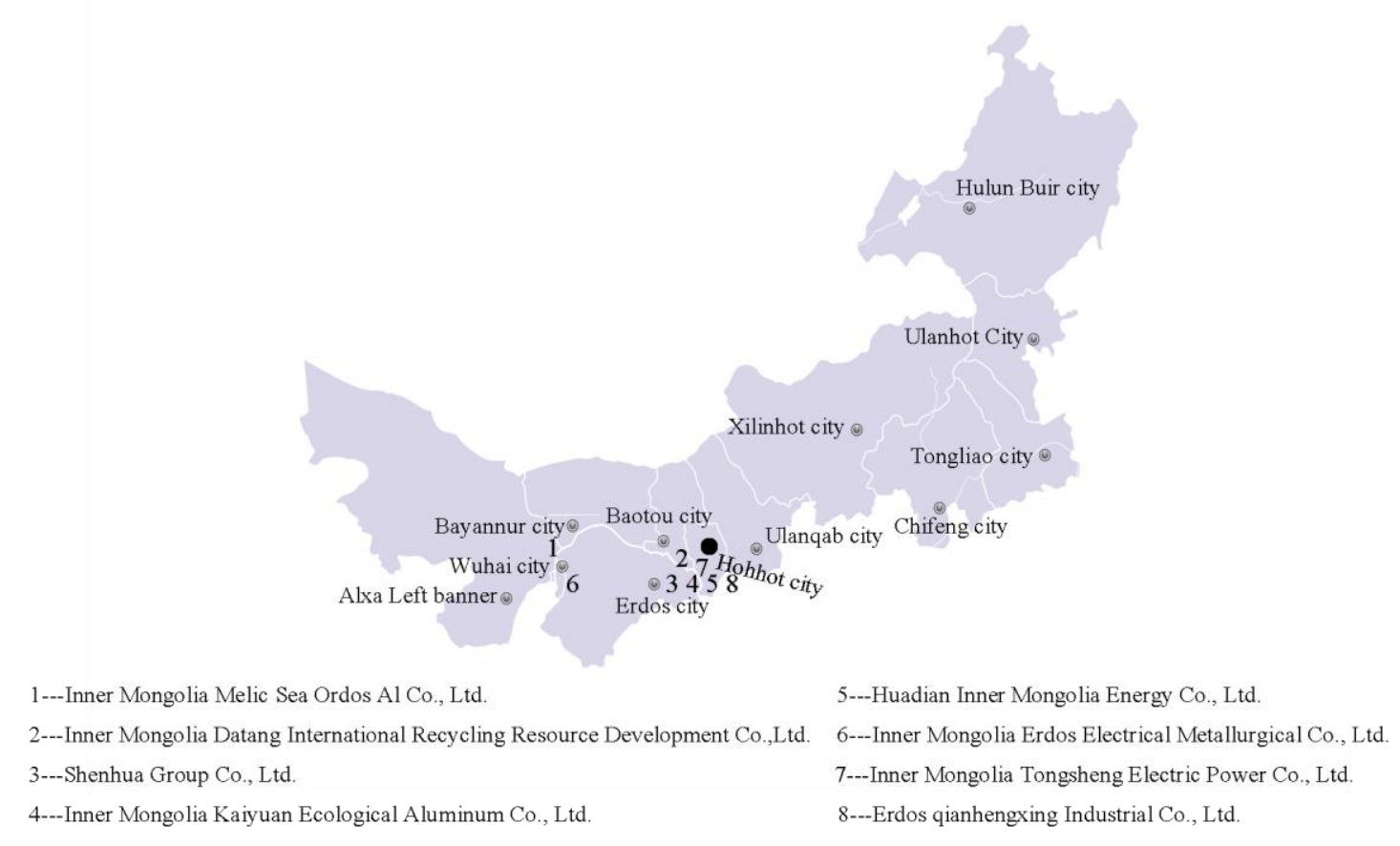

Fig. 6 Distribution of plants for alumina recovery from coal fly ash in China

The Inner-Mongolia Melic Sea Ordos Al Co., Ltd. was established in 2006. Research on alumina recovery from coal fly ash was initiated in 1998. The industrial production test was finished in August 2004, based on a series of mechanism studies, laboratory tests, pilot-scale tests, and small-scale industrial production tests. The project was approved by the NDRC of China in 2006 and the total capital invested has been about 1.6 billion yuan. The technology used for alumina recovery is lime sinter followed 
by a low-temperature Bayer process, developed based on the Polish technology. The schematic diagram of this technology is displayed in Fig. 7.

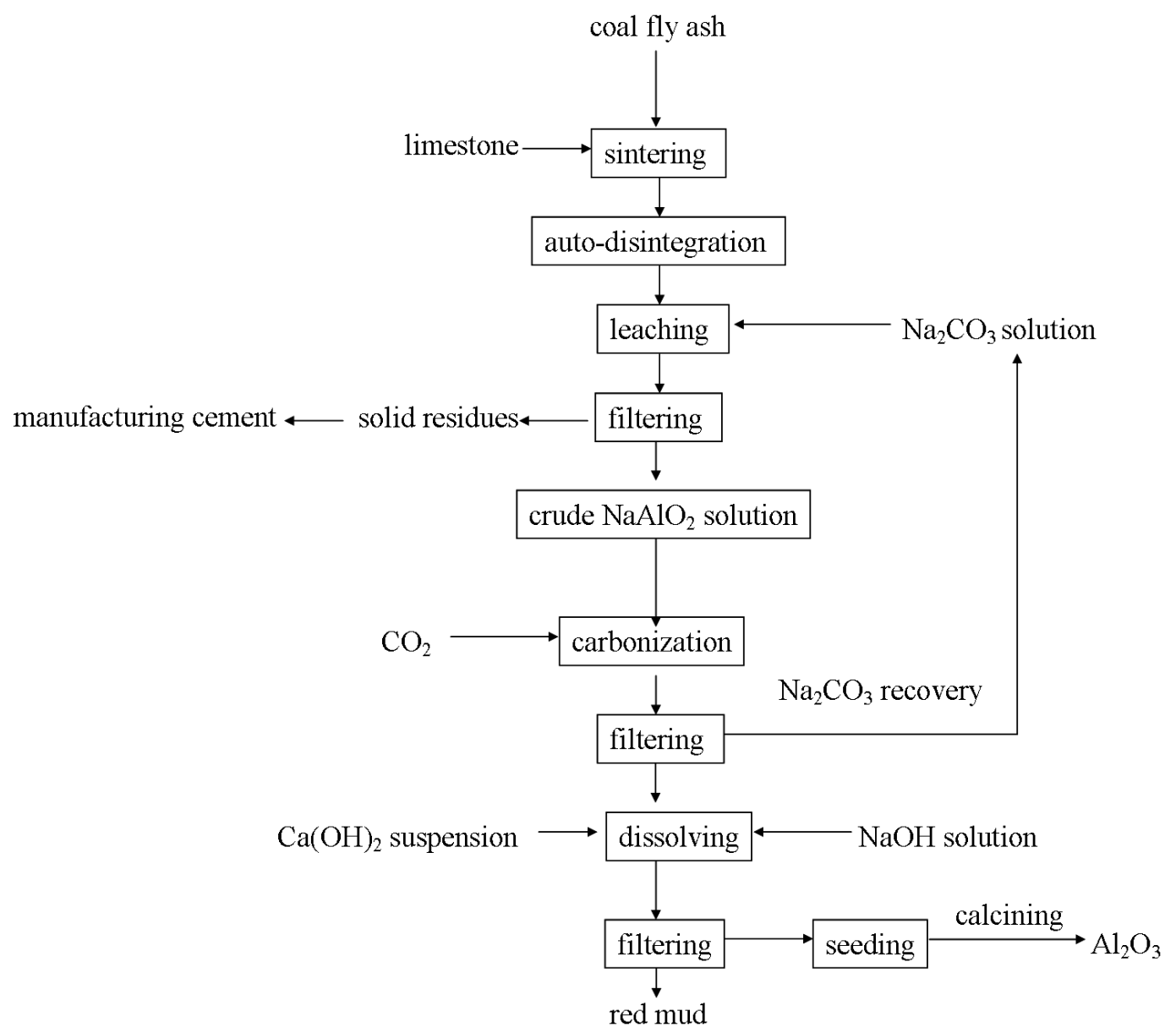

Fig. 7 Schematic diagram of lime sinter followed by Bayer process

The Inner Mongolia Datang International Recycling Resource Development Co., Ltd. was established in 2007. The research on alumina recovery was launched in 2004. The laboratory and industrial tests were accomplished in 2006 and 2008, respectively. The project in Tuoketuo Industrial Park is separated into three phases. Investment for the first and second phases of the project totaled 3.39 billion yuan and the project went into operation in 2012. The designed annual production capacity is 0.24 million tonnes of alumina and 0.2 million tonnes of active calcium silicate. The third phase of the project is 
expected to produce 0.5 million tonnes of alumina and 0.56 million tonnes of active calcium silicate with invested capital of 13.3 billion yuan. Another project located in Erdos city is underway. The alumina recovery technology jointly developed by Tsinghua University is predesilication followed by a lime-soda sinter process. The fly ash is first desilicated removing $~ 40 \%$ of the total silica and doubling the $\mathrm{Al}_{2} \mathrm{O}_{3} / \mathrm{SiO}_{2}$ mass ratio. The desilicated fly ash is then sintered with calcium carbide slag to extract aluminium. A solution rich in silicon is used to prepare active calcium silicate, which could be used as a filler in paper. The calcium silicates residue after neutralization and dehydration could be used as raw material to produce cement. The results showed that the alumina extraction rate could achieve $\sim 90 \%$ and the obtained alumina meets the metallurgical grade standard. The schematic diagram of this technology is displayed in Fig. 8.

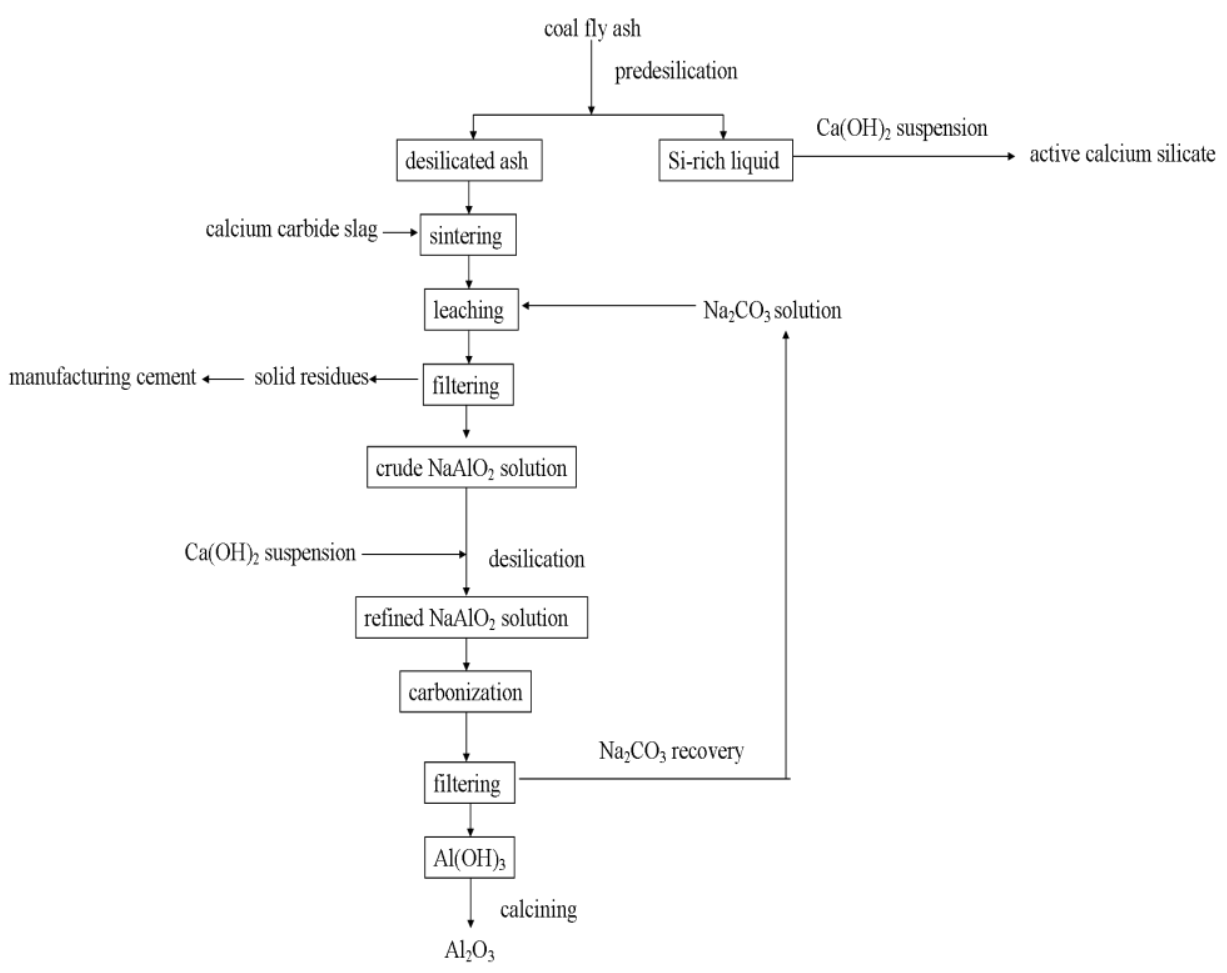

Fig. 8 Schematic diagram of predesilication followed by lime-soda sinter process 
The Shenhua Group Co., Ltd. initiated this research in 2004 and has been working with Jilin University since 2006. The circular economic industry project, oriented toward recovering alumina from fly ash, was planned in 2010 and listed in the "National Science and Technology Pillar Program during the Twelfth Five-year Plan Period.” A pilot-scale plant recovering 4,000 tonnes of alumina with a recovery rate of $80 \%$ was constructed in August 2011. The first-phase demonstration project producing 1 million tonnes of alumina concluded on 25 August 2011 in Zhungeer Banner, Erdos City. The second and third phases of the project are expected to be completed at the end of 2020 and each phase is expected to produce 1 billion tonnes of alumina. The technology jointly developed by Jilin University and Guiyang Aluminium Magnesium Design \& Research Institute Co., Ltd. is a one-step acid leaching, including dissolving fly ash in hydrochloric acid, filtering, evaporating, crystallizing and calcining. The obtained alumina meets the metallurgical grade standard. The schematic diagram of this technology is shown in Fig. 9.

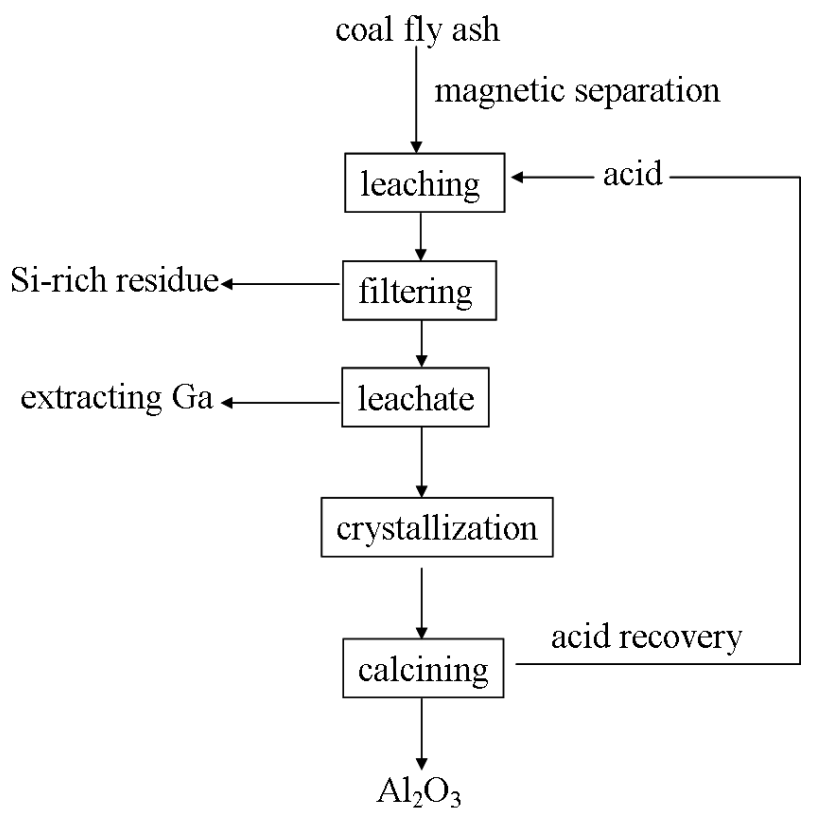


Fig. 9 Schematic diagram of one-step acid leach

The Pingshuo High-tech Research and Development Center was established by China Coal Pingshuo Coal Industry Co., Ltd. and the local government in early 2006. It cooperated with Northeastern University, Xi'an University of Architecture and Technology, and the Institute of Process Engineering, Chinese Academy of Sciences in an alumina recovery project, initiated in 2011 and expected to conclude in September 2013. Alumina production of 0.1 million tonnes, and silica white production of thousands of tonnes, are expected to be achieved. The technology used is similar to that used in the Inner Mongolia Datang International Recycling Resource Development Co. Ltd. The fly ash is first desilicated and the crude $\mathrm{NaAlO}_{2}$ solution carbonized, to prepare the silica white. The desilicated residue is sintered with lime and soda to recover alumina.

The Inner Mongolia Kaiyuan Ecological Aluminum Co. Ltd. is a subsidiary of Beijing Century Harmony Technology Co., Ltd. It signed an agreement with Beijing SPC Environment Protection Technical Co., Ltd. in April 2012 and paid 1.58 million yuan for technology support, plant management and system debugging. The project was initiated in 2012 and is expected to conclude in 2015. It consists of two steps: the first-phase project is anticipated to produce 0.4 million tonnes of alumina and 0.12 million tonnes of Si-rich products with invested capital of 2.4 billion yuan; the second-phase project, 0.6 million tonnes of alumina and 0.18 million tonnes of Si-rich products, with invested capital of 3.6 billion yuan. The technology to be used is low-temperature ammonium sulfate sinter; the schematic diagram is displayed in Fig. 10. 


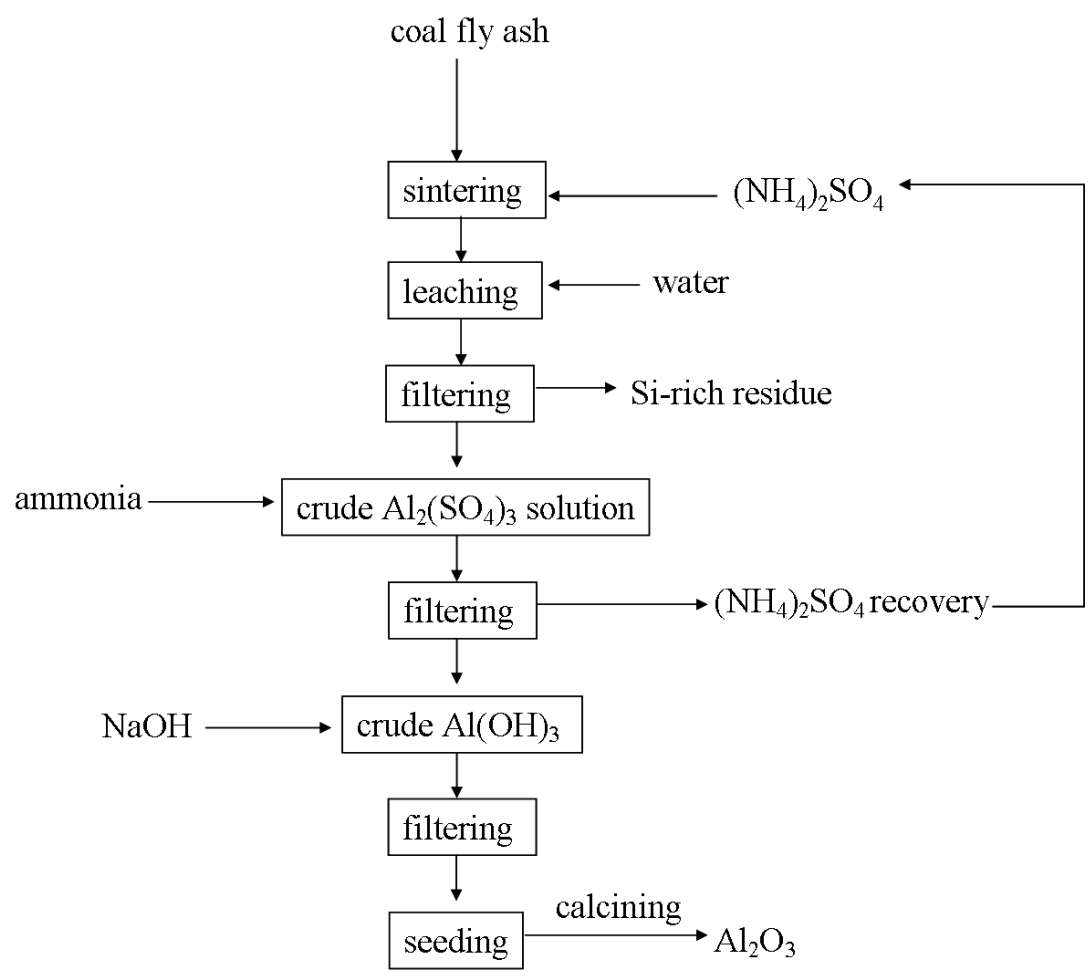

Fig. 10 Schematic diagram of ammonium sulfate sinter

The capital invested in the project in Inner Mongolia Erdos Electrical Metallurgical Co., Ltd. is 5.75 billion yuan, and it is designed primarily to produce 1 million tonnes of alumina at metallurgical grade, along with by-products such as silica white $(0.51$ million tonnes), sodium silicate ( 0.77 million tonnes) and zeolites (6.52 million tonnes). The selected technology is acid leach followed by the Bayer process.

Besides the companies listed in Table 1, other companies are also reported to be initiating this type of research. The Beijing Lucency Environ-tech Co., Ltd. (a subsidiary of the China Guodian Corporation) obtained a technology breakthrough in the decomposition and utilization technology of coal fly ash. In this laboratory test, fly ash was used to produce alumina, silica white and iron oxides with a high extraction rate.

\section{Conclusions and future research}


With the diminishing reserves of bauxite as well as the increasing demand for alumina, recovering alumina from fly ash has attracted extensive attentions. Such research has been seriously undertaken in China. A number of recovery methods have been developed since the pioneering work of Grzymek. However, there are some drawbacks to all these methods and most reported work to date has been at the laboratory scale. The acid leach processes can dissolve aluminium and other metals with silicon-rich residue as by-products. However, it requires acid-resistant and air-tight processing equipment, such as that used in the Shenhua Group Co., Ltd. plant, prepared from tantalum niobium alloy. In addition, alumina recovery and waste treatment can be quite complex. In the leaching process, a proportion of soluble impurities such as $\mathrm{Fe}$, Ti and $\mathrm{Mg}$ contained in the ash are introduced into the pregnant solution, necessitating post-treatment to purify the aluminium; another drawback of the acid process includes the low extraction rate and the necessary cost of environmental protection. Most sinter processes are not related to the simultaneous extraction of alumina and silica. In addition, a generous amount of calcium silicate residues are generated, but not utilized in an effective way except by manufacturing cement. Predesilication and the lime-soda sinter combination process offer the advantages of simultaneously extracting silica and reducing the solid residues to some extent. Other problems, however, such as filtration and the washing of desilicated liquor, are also confronted in the industrial application of these processes. The cost of each tonne of alumina can be hundreds to a thousand yuan higher than that of alumina produced from bauxite using the traditional Bayer process. While fewer residues are produced in the lime-soda sinter process, as compared with the 
lime sinter process, the energy cost is relatively high and the process is complex, problems that have restricted its large-scale application.

Fly ash utilization is expected to increase potential industrial synergy opportunities because of the growth of various applications that can use the by-products of recycled fly ash. However, most reported methods are still in the early stages of commercialization. Further studies are needed to turn this research into commercial reality. The following recommendations can be made based on this research:

1) Investigate the distribution of alumina-rich coal and its flow. Economies of scale can be realized in alumina recovery. The revised "Market Access Conditions for the Aluminum Industry" promulgated by the Ministry of Industry and Information Technology of China, requires that annual alumina production be no less than 500 thousand tonnes for each new plant, and that the company produce more materials or have different types of businesses that include several follow-on products, such as “coal-electricity-ash-alumina/silica/gallium-cement," ash-cenospheres/alumina-aluminum alloy," which could offer synergetic advantages.

2) Because the more recent technologies have their own disadvantages, there should be a greater emphasis on the development of new technology. We can use combinations of processes, such as predesilication followed by a lime-soda sinter process, sinter-acid leach combination process. It is also better to simultaneously recover more valuable materials, such as unburnt carbon, cenospheres, alumina, silica, gallium, titanium, etc. Additional work is needed to optimize the processing steps, particularly in the area of aluminum separation.

3) Long-term economic and environmental impact analysis, using life cycle 
assessment, is needed. There is a scarcity of information on the environmental impacts of fly ash in the preparation of materials ${ }^{[9]}$. Likewise, economic evaluation of the applications would give greater weight to the research; currently economic data are sparse.

4) The distance between fly ash sources and recycling sites need to be taken into account. Generally, fly ash should be transported no more than $100 \mathrm{kms}$, and definitely not more than $200 \mathrm{kms}$; otherwise the production costs of recovery will be prohibitive. To promote the usage of fly ash, state and local governments should issue preferential policies that encourage its recycling, such as the preferential purchase of recycled fly ash products and reduction of the overall effective tax rate for the recycling companies.

\section{Acknowledgements}

We gratefully acknowledge financial support from Scientific Research Foundation

of Hangzhou Dianzi University (Grant no. KYS205612029), Zhejiang Provincial Natural Science Foundation of China (Grant no. LQ13B070005) and Chinese National 863 High Technology (Grant no. 2007AA06Z128).

\section{References}

[1] Blissett RS, Rowson NA. A review of the multi-component utilisation of coal fly ash. Fuel 2012; 97: 1-23.

[2] Ilic M, Cheeseman C, Sollars C, Knight J. Mineralogy and microstructure of sintered lignite coal fly ash. Fuel 2003; 82: 331-6.

[3] Temimi M, Camps JP, Laquerbe M. Valorization of fly ash in the cold stabilization of clay materials. Resour. Conserv. Recy. 1995; 15, 219-34.

[4] Manoharan V, Yunusa IAM, Loganathan P, Lawrie R, Skilbeck CG, Burchett MD, 
Murray BR, Eamus D. Assessments of Class F fly ashes for amelioration of soil acidity and their influence on growth and uptake of Mo and Se by canola. Fuel 2010; 89: 3498-504.

[5] Lee H, Ha HS, Lee CH, Lee YB, Kim PJ. Fly ash effect on improving soil properties and rice productivity in Korean paddy soils. Bioresource Technol. 2006; 97: 1490-7.

[6] Matsi T, Keramidas VZ. Fly ash application on two acid soils and its effect on soil salinity, pH, B, P and on ryegrass growth and composition. Environ. Pollut. 1999; 104: 107-12.

[7] Erol M, Küçükbayrak S, Ersoy-Meriçboyu A. Characterization of sintered coal fly ashes. Fuel 2008; 87: 1334-40.

[8] Yao ZT, Tan SH, Xia MS, Ye Y, Li JH. Synthesis, characterization and sintering behavior of indialite ceramic from fly ash. Waste Manage. Res. 2011; 29: 1090-7.

[9] Erol M, Küçükbayrak S, Ersoy-Meriçboyu A. Comparison of the properties of glass, glass-ceramic and ceramic materials produced from coal fly ash. J. Hazard. Mater. 2008; 153: 418-25.

[10] Jain D, Khatri C, Rani A. Fly ash supported calcium oxide as recyclable solid base catalyst for Knoevenagel condensation reaction. Fuel Process. Technol. 2010; 91: 1015-21.

[11] Saputra E, Muhammad S, Sun HQ, Anga HM, Tadéa MO, Wang SB. Red mud and fly ash supported Co catalysts for phenol oxidation. Catal. Today 2012; 190: 68-72.

[12] Xuan XP, Yue CT, Li SY, Yao Q. Selective catalytic reduction of NO by ammonia with fly ash catalyst. Fuel 2003; 82: 575-9.

[13]Wang SB. Application of solid ash based catalysts in heterogeneous catalysis. 
Environ. Sci. Technol. 2008; 42: 7055-63.

[14] Wang SB, Wu HW. Environmental-benign utilisation of fly ash as low-cost adsorbents. J. Hazard. Mat. 2006; 136: 482-501.

[15]Hirajima T, Petrus HTBM, Oosako Y, Nonaka M, Sasaki K, Ando T. Recovery of cenospheres from fly ash using dry separation process: Separation estimation and potential application. Int. J. Miner. Process. 2010; 95: 18-24.

[16]Niewiadomski M, Hupka J, Bokotko R, Miller JD. Recovery of coke fines from fly ash by air sparged hydrocyclone flotation. Fuel 1999; 78: 161-8.

[17] Shoumkova AS. Magnetic separation of coal fly ash from Bulgarian power plants. Waste Manage. Res. 2011; 29: 1078-89.

[18]Holler H, Wirsching U. Zeolite formation from fly ash. Forsch. Miner. 1985; 63: $21-43$.

[19]Chareonpanich M, Namto T, Kongkachuichay P, Limtrakul J. Synthesis of ZSM-5 zeolite from lignite fly ash and rice husk ash. Fuel Process. Technol. 2004; 85: 1623-34.

[20] Yao ZT, Ye Y, Xia MS. Synthesis and characterization of lithium zeolites with ABW type from coal fly ash. Environ. Prog. Sustain. 2013; 32: 790-6.

[21]Hernandez-Exposito A, Chimenos JM, Fernandez AI, Font O, Querol X, Coca P, Garcia Pena F. Ion flotation of germanium from fly ash aqueous leachates. Chem. Eng. J. 2006; 118: 69-75.

[22] Arroyo Torralvo F, Fernández-Pereira C. Recovery of germanium from real fly ash leachates by ion-exchange extraction. Miner. Eng. 2011; 24: 35-41.

[23]Zheng F, Gesser HD. Recovery of gallium from coal fly ash. Hydrometallurgy, 1996; 
41: $187-200$.

[24] Wang CF, Li JS, Wang LJ, Sun XY. Study on adsorption of Cr (VI) using single-phase zeolites synthesized from fly ash. Chinese J. Environ. Eng. 2008; 2: 1121-6.

[25]European Coal Combustion Products Association. Production and utilisation of CCPs in 2008 in Europe, http://www.ecoba.com/evjm, media/ccps/Ecoba_Stat_2008_EU15.pdf>, 2008.

[26] The American Coal Ash Association. CORRECTED 2009 Coal Combustion Product $\begin{array}{lllll}\text { (CCP) } & \text { Production } & \text { Use } & \text { Survey, }\end{array}$ http://www.acaa-usa.org/associations/8003/files/2009_Production_and_Use_Survey_ Goss_FINAL_110310.pdf, 2010.

[27] Greenpeace. The true cost of coal - an investigation into coal ash in China, http://www.greenpeace.org/usa/en/media-center/reports/The-True-Cost-of-Coal-Coal -Ash-in-China/, 2010.

[28] Vassilev SV, Vassileva CG. Methods for characterization of composition of fly ashes from coal-fired power stations: a critical overview. Energ. Fuel. 2005; 19: 1084-98.

[29] Hosterman JW, Patterson SH, Good EE. World nonbauxite aluminum resources excluding alunite. Washington: U.S. Government Printing Office, 1990, p. 51.

[30] Grzymek J. Prof. Grzymek's self-disintegration method for the complex manufacture of aluminum oxide and portland cement. Proceedings of sessions 105th AIME annual meeting, Las Vegas, Nevada, 1976, p. 29-39.

[31] Bayer KJ. A process for the production of aluminium hydroxide. German Patent 43,977, 03-08-1888. 
[32]Pedcrsen H. Improved process for the production of iron from ores. British Patent 232,930, 23-04-1924

[33]Pedersen H. Process of manufacturing aluminum hydroxide. US Patent 1,618,105, 15-02-1927.

[34]Padilla R, Sohn HY. Sodium aluminate leaching and desilication in lime-soda sinter process for alumina from coal wastes. Metall. Mater. Trans. B 1985, 16(4): 707-13.

[35]Hignett TP. Production of alumina from clay by a modified Pederson process. Ind. Eng. Chem. 1947; 39(8): 1052-60.

[36] Eriksson J, Björkman B. MgO modification of slag from stainless steelmaking. VII International Conference on Molten Slags Fluxes and Salts, The South African Institute of Mining and Metallurgy, 2004, p. 455-60.

[37]Guzzon M, Mapelli C, Memoli F, Marcozzi M. Recycling of ladle slag in the EAF: improvement of the foaming behavior and decrease of the environmental impact. Revue de Métallurgie, 2007; 104: 171-8.

[38] Archibald FR, Nicholson CM. Alumina from clay by the lime-sinter method II. Transactions of the American Institute of Mining and Metallurgical Engineers, 1949; 182: $14-38$.

[39]Lin HY, Wan L, Yang YF. Aluminium hydroxide ultrafine powder extracted from fly ash. Adv. Mater. Res. 2012; 512-515: 1548-53.

[40] Kayser A. Process of separating alumina from silica. US Patent 708,561, 09-09-1902.

[41]Padilla R, Sohn HY. Sintering kinetics and alumina yield in lime-soda sinter process for alumina from coal wastes. Metall. Mater. Trans. B 1985, 16(2): 385-95.

[42]Chesley JA, Burnet G. Sulfate-resistant portland cement from lime-soda sinter 
process residue. Mat. Res. Soc. Symp. Proc. 1998; 113: 163-71.

[43] Wang MW, Yang J, Ma HW, Shen J, Li JH, Guo F. Extraction of aluminum hydroxide from coal fly ash by pre-desilication and calcination methods. Adv. Mater. Res. 2012; 396-398: 706-10.

[44]Bai GH, Teng W, Wang XG, Qin JG, Xu P, Li PC. Alkali desilicated coal fly ash as substitute of bauxite in lime-soda sintering process for aluminum production. Trans. Nonferrous Met. Soc. China 2010; 20: s169-75.

[45]Bai GH, Teng W, Wang XG, Zhang H, Xu P. Processing and kinetics studies on the alumina enrichment of coal fly ash by fractionating silicon dioxide as nano particles. Fuel Process. Technol. 2010; 91: 175-84.

[46] Goodboy KP. Investigation of a sinter process for extraction of $\mathrm{Al}_{2} \mathrm{O}_{3}$ from coal wastes. Metall. Mater. Trans. B 1976; 7: 716-8.

[47] Seeley FG, McDowell WJ, Felker LK, Kelmers AD, Egan BZ. Determination of extraction equilibria for several metals in the development of a process designed to recover aluminum and other metals from coal combustion ash. Hydrometallurgy 1981; 6: 277-90.

[48] McDowell WJ, Seeley FG. Salt-soda sinter process for recovering aluminum from fly ash. US patent 4254088, 03-03-1981.

[49]Decarlo VA, Seeley FG, Canon RM, Mcdowell WJ, Brown KB. Evaluation of potential processes for the recovery of resource. Oak Ridge National Laboratory, ORNL/TM-6126, 1978.

[50]Nehari S, Gorin C, Lin IJ, Berkovich A. Process for recovery of alumina and silica. US patent 5993758, 12-12-1996. 
[51]Tong ZF, Zou YF, Li YJ. Roasting activation mechanism of coal fly ash with KF assistant. Chin. J. Nonferrous Met. 2008, 18: s403-6.

[52] Mohamed MA, Kassim ME, El-Katatny EA. Optimization of the extraction of aluminum sulfate and ammonium aluminum sulfate alums from aluminum dross tailings. J. Mater. Res. 1998; 13: 1075-83.

[53]Park HC, Park YJ, Stevens R. Synthesis of alumina from high purity alum derived from coal fly ash. Mat. Sci. Eng. A-Struct. 2004; 367: 166-70.

[54]Kelmers AD, Canon RM, Egan BZ, Felker LK, Gilliam TM, Jones G, Owen GD, Seeley FG, Watson JS. Chemistry of the direct acid leach, calsinter, and pressure digestion-acid leach methods for recovery of aluminum from fly-ash. Resour. Conserv. 1982; 9: 271-9.

[55] Seidel A, Zimmels Y. Mechanism and kinetics of aluminum and iron leaching from coal fly ash by sulfuric acid. Chem. Eng. Sci. 1998; 53: 3835-52.

[56] Shemi A, Mpana RN, Ndlovu S, van Dyk LD, Sibanda V, Seepe L. Alternative techniques for extracting alumina from coal fly ash. Miner. Eng. 2012; 34: 30-7.

[57] Gudyanga FP, Togara F, Harlen RM. Extraction of alumina from pulverised fly ash: Hwange power station. AFRICON '92 Proceedings, 3rd AFRICON Conference, IEEE, South Africa, 22-24 Septemper 1992, p. 77-80.

[58] Verbaan B, Louw GKE. A mass and energy balance model for the leaching of a pulverised fuel ash in concentrated sulphuric acid. Hydrometallurgy 1989; 21: $305-17$.

[59] Ayres RU, Ayres LW. Coal ash: sources and possible uses. In: Material-cycle optimisation in the production of major finished materials. INSEAD's Center for the 
Management of Environmental Resources, BRE2-CT93-0894. Fontainebleau, France, 1995.

[60] Wu CY, Yu HF, Zhang HF. Extraction of aluminum by pressure acid-leaching method from coal fly ash. Trans. Nonferrous Met. Soc. China 2012; 22: 2282-8.

[61]Gong MM. Research on the leaching process of coal fly ash assisted by microwave irradiation in hydrochloride acid solution. East China University of Science and Technology, Master's dissertation, Shanghai, 2011.

[62]Liu K, Xue JL, Zhu J. Extracting Alumina from fly ash using acid sintering-leaching process. In: Light Metals, Suarez CE, (Ed.), John Wiley \& Sons Inc, 2012, p. 201-6.

[63]Bai GH, Qiao YH, Shen B, Chen SL. Thermal decomposition of coal fly ash by concentrated sulfuric acid and alumina extraction process based on it. Fuel Process. Technol. 2011; 92: 1213-9.

[64]Ji HM, Lu HX, Hao XG, Wu P. High purity aluminia powders extracted from fly ash by the calcing-leaching process. J. Chinese Ceram. Soc. 2007; 35: 1657-60.

[65] Matjie RH, Bunt JR, van Heerden JHP. Extraction of alumina from coal fly ash generated from a selected low rank bituminous South African coal. Miner. Eng. 2005; 18: 299-310.

[66]Burnet G, Murtha MJ, Wijatno H. 3rd Kentucky Coal Refuse Disposal and Utilization Seminar, 11-12 May, 1977, Lexington, Kentucky, p. 83.

[67] Mehrotra AK, Behle LA, Raj Blshnol P, Svrcek WY. High-temperature chlorination of coal ash in a fluidized bed. 1. recovery of aluminum. Ind. Eng. Chem. Process Des. Dev. 1982; 21: 37-44.

[68] Ma BG, Qi M, Peng J, Li ZJ. The compositions, surface texture, absorption, and 
binding properties of fly ash in China. Environ. Int. 1999; 25(4): 423-32.

[69] Authier-Martin M, Forte G, Ostap S, See J. The mineralogy of bauxite for producing smelter-grade alumina. JOM-J. Min. Mat. S. 2001; 53: 36-40.

[70]Iyer R. The surface chemistry of leaching coal fly ash. J. Hazard. Mater. B 2002; 93: 321-29. 